\title{
Contributions Since the Health Economy Research to the Smoking Control in Cuba
}

\author{
Fé Fernández Hernández ${ }^{1 *}$ and Efraín Sánchez González ${ }^{2}$ \\ ${ }^{1}$ Auxiliary Professor, Faculty of medical science "10 de octubre", Cuba \\ ${ }^{2}$ Asistant Professor, Faculty of medical science "10 de octubre", Cuba
}

*Corresponding author: Fé Fernández Hernández, Auxiliary Professor, University of medical science of Havana, Faculty

of medical science "10 de octubre", Cuba

\section{ARTICLE INFO}

Received: 慧 September 01, 2020

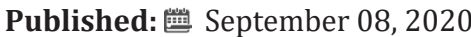

Citation: Fé Fernández Hernández, Efraín Sánchez González. Contributions Since the Health Economy Research to the Smoking Control in Cuba. Biomed J Sci \& Tech Res 30(1)-2020. BJSTR. MS.ID.004901.

\section{ABSTRACT}

Smoking is a polemic risk factor for the Cuban Public Health. This is because of the whole socioeconomic effects from smoking over Cuban society.The tobacco development strategic until 2030 is clearly against the interesting from the Public Health.This strategic suggest that fiscal benefits will contribute to finance the budgets from social sectors as Public Health. The Cuban tobacco sector is applying to economic arguments to justify their own strategic. That's why the Cuban Public Health must straight the economic arguments against smoking. It is necessary the implementation of an integral strategic for a better control from smoking. As part of that strategic the postgraduate education may plays an active role for a better smoking control. The academic results from research may meet important elements since the Health Economy to use in an integral strategic for the smoking control.
\end{abstract}

Keywords: Smoking;Control;Research

\section{Short Communication}

The complete economic evaluations for the Public Health are useful tools for taking decisions process. In fact, this economic evaluation method had supported it own utilization in the strategic planning [1]. The health economic evaluation cost - benefit is the more orthodox since the economic point of view because costs and benefits are measured in monetary units. This condition makes easier the economic analysis for the Public Health [2]. Smoking is a polemic risk factor for the Cuban Public Health. This is because of the whole socioeconomic effects from smoking over Cuban society. The health economic evaluation cost - benefit had been take as reference to show that in Cuba is better produce and consume tobacco products because carries to more benefits than cost [3]. Recent researches from Cuba are suggesting that:

1) The dynamic from the costs attributable to smoking is higher than in benefits case[4].

2) Cigarettes and tobaccos are showing a tendency as necessaries and ordinaries economic goods. Also, the relation between price and demand is very inelastic. This condition makes more difficult the utilization from the tributary policy for the smoking control[5].

3) The present fiscal policy for the smoking control isn't agrees to the domestic tobacco market behavior[6].

By other side the tobacco development strategic until 2030 is clearly against the interesting from the Public Health. This strategic suggest that fiscal benefits will contribute to finance the budgets from social sectors as Public Health. This economic sector is applying for:

1) Diversify and increase productions agree to the market demand. This condition will make more efficient this economic sector.

2) Offer more production looking for teenagers as tobacco consumption beginners[7].

The Cuban Public Health most assumes a stronger role against smoking. From the 10 main death causes in Cuba, at least six are close related to smoking [8]. In the Oncology and Radiology National 
Institute in 2015 , more than the $40 \%$ from the institutional budget was utilized because of smoking [9]. The Cuban tobacco sector is applying to economic arguments to justify their own strategic. That's why the Cuban Public Health must straight the economic arguments against smoking [10]. It is necessary the implementation of an integral strategic for a better control from smoking. As part of that strategic the postgraduate education may plays an active role for a better smoking control [11]. An example of that is the docent research project "Costo - beneficio directo fiscal del tabaquismo en Cuba" from the Faculty of Medical Science "10 de Octubre" from the University of Medical Science of Havana. The scientific results from this research project include:

a. Describe the relation between smoking and the labor health [12]

b. Characterization of the labor productivity loses attributable to smoking[13].

c. The description of the labor productivity loses because of the tobacco consumption during the labor time in Cuba in 2011[14].

d. The description of the social cost because of the earlier smokers' death in Cuba in 2011[15].

e. The description of the morbidity attributable to smoking since the economic point of view[16].

f. Characterization of process estimating the economic burden from a risk factor[17].

g. Introduce [18] and validate analytically [19] a new formula to estimate the smoking economic burden by morbidity.

h. Design an algorithm to calculate the smoking economic burden by morbidity[20].

i. The description of the fiscal authorities role in the smoking control[21].

j. Characterization of the socioeconomic inequity attributable to smoking[22].

k. The description of the socioeconomic inequity attributable to smoking since the social cost attributable to smoking[23].

l. Introduce several rates to measure the socioeconomic inequity attributable to smoking[24].

m. Describe the structure from the tobacco consumption in Cuba by region from 2013 to 2016[25].

n. Describe the role of the primary public health server in the economic smoking control[26].

o. Introduce a postgraduate course[27] and three diploma course[11,28,29]supporting the smoking economic control since the Health Economy.
Moreover these result it is important to understand that much smoking social consequences are outside Public Health hands. The untouchable costs attributable to smoking as earlier death and reduction of life quality are more valuated while more interesting is considered the life and it quality. That's why the economic argument against smoking must include the social analysis too [30]. The explication of smoking impact must be moreover the clinical consequences. It is important the inclusion of positivist point of view to support epidemiologic research about smoking [31].

\section{Conclusion}

Cuban Public Health needs straight the economic arguments against smoking. The academic results from research may meet important elements since the Health Economy to use in an integral strategic for the smoking control.

\section{References}

1. Fernández Hernández F, Sánchez González E (2020) A postgraduate course for the decision taking in the Public Health context. Journal of Medical Care Research and Review 3(8):413-416.

2. Fernández Hernández F, Sánchez González E (2019) Health Economic Evaluations for the Health Education Management. International Journal of Education Advancement 2019(1).

3. Sánchez González E, Fernández Hernández F (2019) The smoking fiscal space in Cuba. Journal of Clinical and Medical Research 1(3): 1-5.

4. Fernández Hernández F, Sánchez González E (2017) Impacto del tabaquismo en el presupuesto sanitario de Cuba 1997-2014. Revista del Hospital Psiquiátrico de La Habana.

5. Sánchez González E, Fernández Hernández F (2017) Caracterización económica general del consumo de cigarrillos en Cuba de 2011 a 2013. Revista del Hospital Psiquiátrico de La Habana.

6. Sánchez González E, Fernández Hernández F (2018) La relación entre la política tributaria y el control del tabaquismo en Cuba. Correo Científico Médico de Holguín 2: 238-249.

7. (2020) ENPA. Actualización del programa integral de desarrollo para producción de tabaco en Cuba.

8. ONEI. Anuario Estadístico de Cuba. 2020. La Habana.

9. Fernández Hernández F, Sánchez González E (2020) The smoking economic burden in the national institute on oncology and radiology from Cuba. Journal of Physical medical \& Rehabitation studies \& Report $2(2)$.

10. Sánchez González E, Fernández Hernández F (2020) The fiscal policy and the smoking control in Cuba. Journal of Clinical Research and Reports 2(4).

11. Fernández Hernández F, Sánchez González E (2019) Diploma Course: "The Social Smoking Cost in the National Economy", A Necessary and Appliable Tool. HSOA Journal of Community Medicine and Public Health Care 6(052).

12. Fernández Hernández F, Sánchez González E (2020) Smoking incidence over the labor health. Journal of Medical Care Research and Review 03(08): 417-419.

13. Sánchez González E, Fernández Hernández F (2016) La pérdida de productividad laboral atribuible al tabaquismo. Revista Cubana de Salud y Trabajo 17(2): 57-60.

14. Fernández Hernández F, Sánchez González E (2017) Pérdida de productividad por el consumo de cigarrillos en la jornada laboral. Revista Cubana de Salud y Trabajo 18(3): 9-12. 
15. Sánchez González E, Fernández Hernández F (2017) Costo de oportunidad por muerte prematura de fumadores activos cubanos en el 2011. Cubana de Salud y Trabajo 18(2): 26-31.

16. Sánchez González E, Fernández Hernández F (2019) A view for the morbidity attributable to smoking since the microeconomic. OAT Trends in Research 2.

17. Fernández Hernández F, Sánchez González E (2019) Estimating the economic burden attributable to some risk factor. OAT Journal of Clinical Investigation and Studies 2.

18. Fernández Hernández F, Sánchez González E (2017) Carga epidemiológica vs carga económica del tabaquismo por morbilidad. Revista de Ciencias Médicas de Pinar del Río 21(2): 210-216.

19. Fernández Hernández F, Sánchez González E (2020) Analytic validation of a formula estimating the smoking economic burden. MOJ Public Health 9(1): 5-7.

20. Fernández Hernández F, Sánchez González E (2018) Algorithm to calculate the smoking economical burden in active and passive smokers. MOJ Toxicology 4(6): 373-375.

21. Sánchez González E, Fernández Hernández F (2017) El rol de las autoridades fiscales en el control del tabaquismo. Revista de Ciencias Médicas de Pinar del Río 21(3): 362-367.

22. Sánchez González E, Fernández Hernández F (2020) Characterization of the Socioeconomic Inequity Attributable to Smoking. Journal of Quality in Health care \& Economics 3(4).

23. Sánchez González E, Fernández Hernández F (2019) The social inequity across the smoking social costs. Ageing Science \& Mental Health Studies $3(5): 1-3$

\section{ISSN: 2574-1241}

DOI: 10.26717/BJSTR.2020.30.004901

Fé Fernández Hernández. Biomed J Sci \& Tech Res

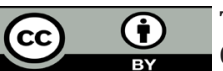

This work is licensed under Creative Commons Attribution 4.0 License

Submission Link: https://biomedres.us/submit-manuscript.php
24. Sánchez González E, Fernández Hernández F (2020) Rates to Measures the Social Inequity Attributable To Smoking. Journal of Clinical Research and Reports 2(4).

25. Sánchez González E, Fernández Hernández F (2020) Personal spend on cigarettes and tobaccos in Cuba from 2013 to 2016. Clinical Reviews and Clinical Trials 2(2).

26. Fernández Hernández F, Sánchez González E (2020) The smoking economic control across the primary health services. Clinical Reviews and Clinical Trials 2(2).

27. Fernández Hernández F, Sánchez González E (2020) A postgraduate course for the decision taking in the Public Health context. Journal of Medical Care Research and Review 03(08): 413-416.

28. Fernández Hernández F, Sánchez González E (2020) Diploma course: "Health Economy tools for taking decisions", a useful tool for health managers. Clinical Reviews and Clinical Trials 2(2).

29. Fernández Hernández F, Sánchez González E (2020) University of Medical Science of Havana Faculty of Medical Science "10 de Octubre" Diploma course: The socioeconomic inequity attributable to smoking. Clinical Reviews and Clinical Trials 2(2).

30. Sánchez González E, Fernández Hernández F (2020) Brief Appointments about Fiscal Policy for the Smoking Control. Journal of Clinical Research and Reports 2(5).

31. Fernández Hernández F, Sánchez González E (2020) Quantitative methods to explain the smoking economic impact. International Journal of Science and Academic Research 1(1): 1-2.

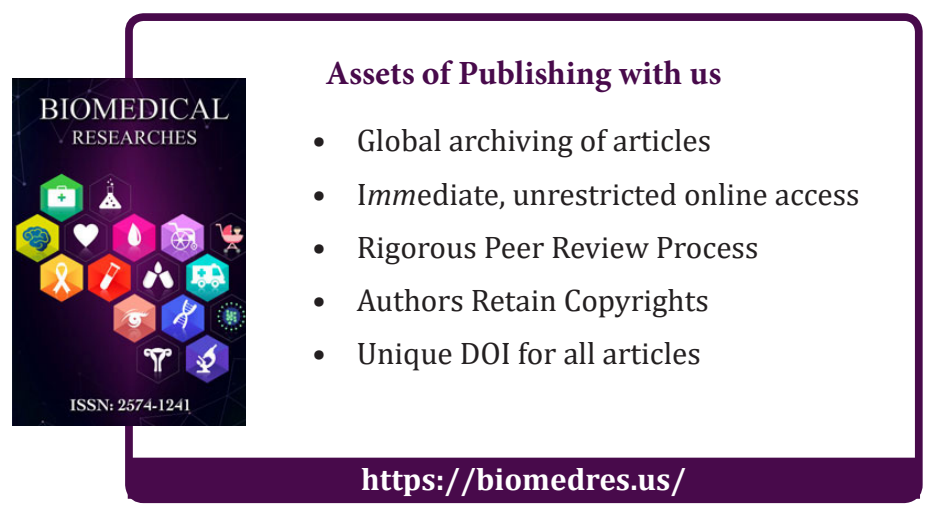

